\title{
Discipline Character Implementation in Pesantren An- Nisiniyyah Wal Muzainiyyah in Facing The Spread of Covid-19
}

\author{
Saridudin ${ }^{1}$, Munawiroh $^{2}$ \\ \{dudinsaridudin@gmail.com ${ }^{1}$, mun.asrori@gmail.com ${ }^{2}$ \} \\ Center for Religious and Religious Education \\ Religious Research, Development and Training Agency, Ministry of Religious Affairs ${ }^{1,2}$
}

\begin{abstract}
This study aims to describe the views of Pesantren An-Nisiniyyah WalMuzainiyyah about Covid-19 and the implementation of the disciplinary character developed by the Pesantren in dealing with the spread of Covid-19. This research is field research, using a qualitative method. Researchers go directly to digging up data through observation, interviews, and documentation studies. The results showed that during the Covid-19 period, Pesantren An-Nisiniyyah Wal-Muzainiyyah did not return its students like other Pesantrens, because the pesantren was very sure that Covid-19 did not exist, the pesantren leadership did not believe in the existence of Covid-19. But institutionally as good citizens, pesantren respect government policies. This was proven when students, religious teachers, or administrators left the pesantren - for a purpose, they were obliged to follow health protocols such as wearing masks, washing hands, maintaining distance, and so on. In responding to Covid-19, Pesantrens emphasize discipline to students in maintaining cleanliness and carrying out a clean lifestyle. The research recommends that the Government should socialize about the dangers of the Corona Virus by coming directly to the Pesantren An-Nisiniyyah Mal-Muzainiyyah. The government should communicate well with pesantrens and make every effort to ensure that the Corona virus is true, and is a very dangerous virus in the world.
\end{abstract}

Keywords: Disciplinary character, Covid 19.

\section{Introduction}

It cannot be denied that the spread of Covid-19 has become a world threat in the health sector. Now the world's population is threatened with death and the world is declaring war against the deadly corona virus. Since March 2020 the Indonesian Government has declared to unite against Covid-19 by forming a Task Force for the Acceleration of Handling Covid-19 and imposing PSBB (Large-Scale Social Restrictions) for several regions. Not to mention that the number of Covid-19 transmissions has decreased, the consequences of this policy have emerged, namely, panic and life difficulties due to restrictions in various sectors. On the other hand, there are increasing speculation and conspiracy theories about Covid-19 as a contagious and deadly epidemic in society, which sometimes contradicts the spirit of fighting Covid-19. Sometimes it even adds to panic in the community about this outbreak. Of the various sectors 
There is a diversity of pesantren in dealing with the Covid-19 epidemic in implementing policies for the implementation of education in Pesantrens, namely: 1) Pesantren which from the outset carried out a policy of repatriating students during the Covid-19 pandemic, and conducting distance learning (PJJ) or online at home, 2 ) pesantren that still carry out the direct learning process by not sending their students home. Likewise, when the development of the Covid-19 pandemic in Indonesia had not experienced a significant decline, the government instead implemented a "New Normal" policy or New Habit Adaptation (AKB) in various sectors including pesantren education institutions.

For pesantrens that carry out learning during the AKB period, four main provisions apply, namely: (1) Forming a task force to accelerate the handling of Covid-19; (2) Having facilities that comply with health protocols; (3) Covid-19 safe, proven by a certificate from the task force to accelerate the handling of Covid-19 or the local government; and (4) Leaders, managers, educators, and students are in good health, proven by a health certificate from the local health service facility. These four provisions must be used as a joint guide for pesantren and religious education institutions that will hold lessons during the Covid-19 pandemic.

In contrast to the provisions set by the government of Pesantren An-Nisiniyyah Wal Muzainiyyah, which is located at Jl. Marsekal Surya Dharma RT 001/07 Gg. Yayasan Pasar Sore, Selapajang Jaya, Neglasari Tangerang has its policy in carrying out its learning activities. This pesantren did not send its students home for several reasons (1) the pesantren leadership did not believe in the existence of Covid-19, (2) the pesantren had an activist agenda that had been prepared, (3) the scope of the students did not meet many people too often, especially from outside, (4) ) The rules for Pesantrens were also tightened, namely by limiting visits from outside people.

Pesantren An-Nisiniyyah Wal-Muzainiyyah does not strictly implement health protocols as recommended by the government, such as wearing masks and maintaining distance, but emphasizes students to apply Islamic teachings such as cleanliness, faith to avoid various outbreaks and diseases, such as the practice of ablution., which is the implementation of a clean and healthy life. The faith of the students is also being trained so that they can be calm in facing the issue of the corona virus outbreak. Although the leadership of Pesantren An-Nisiniyyah Wal -Muzainiyyah does not believe and believe in the existence of Corona, the pesantren advises all pesantren residents, when traveling outside, to comply with health protocols required by the government such as wearing masks, washing hands, and keeping your distance. This is because Pesantren An-Nisiniyyah Wal-Muzainiyyah respects and obeys the rules set by the government.

This study looks at how the Pesantren An-Nisiniyyah Wal-Muzainiyyah applies a disciplined character in carrying out various activities during the Covid-19 period. Little studies on the character of discipline were carried out by pesantren during the Comid 19 pandemic. Several studies have focused more on learning innovations carried out by Pesantrens during the Covid-19 pandemic, paying less attention to disciplinary aspects as the main success factor in preventing the spread of an epidemic, or achieving a goal. This study focuses more on the discipline factor as the main factor in preventing the spread of an outbreak or disease.

This research is based on the assumption that all Pesantrens in carrying out their learning activities during the Covid-19 pandemic will comply with all health protocols required by the government, and believe that Covid-19 is real around us, and everyone must be obedient and disciplined in implementing it. Health protocols that have been established by the government in their activities so that this virus does not spread and endanger everyone, especially the residents of the Pesantren students, kyai, ustad, and the surrounding community. The problems in this research are (1) What is the view of Pesantren An-Nisiniyyah Wal-Muzainiyyah about "COVID 19" and New Normal Life ?, (2) How is the implementation of the disciplinary character 
developed by Pesantren An-Nisiniyyah Wal-Muzainiyyah in dealing with the spread of "COVID 19 "?, (3) What are the implications of the discipline character for the behavior of the students?

\section{Literature Review}

In a pandemic like now, the level of community discipline is being tested because to break the chain of transmission of the Covid-19 Virus requires public discipline to always implement the health protocol recommended by the government. The development of this disciplinary attitude is by following health protocols, such as: (1) always using a mask. Currently, wearing a mask when outside the home or interacting with other people is a must, and has become a habit. Even in some regions, everyone must wear a mask if they are in that area, otherwise, they will be given strict sanctions. (2) A culture of washing hands with soap in running water or using a hand sanitizer when touching the face. To cultivate handwashing, children were taught how to wash hands properly and assigned students to make a video on how to wash hands properly. (3) Maintain a distance of 1 to 1.5 meters, this is to avoid large crowds. (4) Always maintain body immunity by eating nutritionally balanced foods and exercising regularly.

Several studies that are relevant to this research include Purandina and Winaya (2020) in their research entitled Character Education in the Family Environment During Distance Learning during the Covid-19 Pandemic. Researchers have found that the current Covid-19 Pandemic has transformed a large part of people's lives. So far, character education, which seems stagnant and new to the conceptual order, has now shifted to habit. Character building becomes a habit when the activity of instilling character values is repeated regularly until it becomes a habit, which eventually becomes not only a habit but has become a character. The development of character values in children will be very effective if it involves parents and families. ${ }^{1}$ In the current Covid-19 pandemic, collaboration in the roles of families, teachers, and the surrounding community is very important in developing children's character values. In this study, data was obtained that the character values developed by parents in children during the Covid-19 pandemic were (1) religious, (2) disciplinary character values, (3) creative character values, (4) character values independent, (5) the value of the character of responsibility, and (6) the value of the character of curiosity. The development of character values, of course, is a very extraordinary change in terms of the development of children's character. The success of developing character values in these children cannot be separated from the role of teachers and parents to be willing to transform so that they can be used as role models for implementing good character in themselves. This is the momentum of character education in the family environment. With the hope that until this pandemic ends the pattern of character education in this family environment will continue.

Prawoto, Rohmah, and Sunarya (2020) in their research on the Preventive Role of Leaders in Preventing the Spread of Covid-19; The strategy of Syaykh Al-Zaytun in Ma'had Al-Zaytun and Its Contribution to the Surrounding Community reveals that the corona pandemic that has hit the world has never subsided. It takes serious handling and prevention from the government and all elements of society, including the leaders and public figures in this country. In this case, Syaykh Al-Zaytun as the leader of the Pesantren has provided a concrete example in the

${ }^{1}$ I Putu Yoga Purandina dan I Made Astra Winaya, Character Education in the Family Environment During Distance Learning during the COVID-19 Pandemic, Cetta: Jurnal Ilmu Pendidikan, Jayapangus Press ISSN 2615-0913 (E) Vol. 3 No. 2 (2020). https://doi.org/10.37329/cetta.v3i2.454. 
prevention of Covid-19 in the Ma'had Al-Zaytun environment seriously and comprehensively. The prevention of Covid-19 is carried out with various strategies and policies that must be implemented by the Ma'had Al-Zaytun community. Among them are physical strategies, spiritual strategies, and psychological strategies.

The physical strategy is in the form of regulation in terms of logistics, the arrangement of living and working places during the lockdown, regulation in terms of anticipating the immune system, and regulation of creating a healthy environment. The spiritual strategy is carried out by increasing the number of worship in the month of Ramadan. Among them are multiplying the reading of the Al-Qur'an, the dhikr of Asmaul Husna and the Prophet, as well as tarawih prayers. Psychological strategies are carried out by strengthening the body's resilience, namely by always thinking and acting positively; kind, sincere, patient, grateful, honest, and trustworthy. Thus it can be expected that the body's resistance will be stronger and can ward off various kinds of bacteria and viruses, including Covid-19. ${ }^{2}$

Tanshzil (2020) in a research entitled Model of Character Education Development in the Pesantren Environment in Building the Independence and Discipline of Santri (A study on the development of Citizenship Education). The research findings reveal (1) The elements of character values developed in the K.H.Zainal Mustofa boarding school environment include fundamental, instrumental, and praxis values sourced from the Al-Qur'an and Al-Hadith as well as the noble values of Pancasila. (2) The process of fostering character education in building independence and discipline of students in the KH. Zainal Mustafa Pesantren environment is carried out with a comprehensive approach, through learning, extracurricular activities, habituation, and collaboration with the community and family. (3) Methods used in building independence as well as the discipline of students in the KH. Zainal Mustafa boarding school environment is implemented through the habituation method, the provision of lessons or advice, the method of reward and sanctions, as well as the exemplary method of the Kiai and their teachers. (4) The obstacles faced in implementing character-building methods in building independence and discipline of students at KH Zainal Mustafa's Pesantren are internal and external. (5) The superiority of the results developed in building the independence and discipline of students at the KH. Zainal Mustofa was proven by the change in attitude, manners, and behavior of the students; the emergence of independent students in thinking and acting; The discipline of students in managing time and obeying regulations, as well as the emergence of role models in the community, both in the fields of education, religion, health, and social organizations. ${ }^{3}$

Wuryandani, Maftuh, Sapriya, and Budimansyah (2014) revealed that based on this research at SD Muhammadiyah Sapen Yogyakarta, to support the successful internalization of the value of disciplinary character in this school, nine school policies were made, namely character education programs, setting school rules and class rules, perform Dhuha prayers and Dhuhur prayers in congregation, create affective posts in each class, monitor student disciplinary behavior at home through daily activity logbooks, provide effective messages in various corners of the school, involve parents, involve school committees, and create a

\footnotetext{
${ }^{2}$ Imam Prawoto, Siti Ngainnur Rohmah, Fitri Rachmiati Sunarya, The Preventive Role of Leaders in Preventing the Spread of COVID-19; Strategi Syaykh Al-Zaytun di Ma'had Al-Zaytun dan Kontribusinya Terhadap Masyarakat Sekitar, SALAM; Jurnal Sosial \& Budaya Syar'i FSH UIN Syarif Hidayatullah Jakarta Vol. 7 No. 5 (2020), pp. 403-422, DOI: 10.15408/sjsbs.v7i5.15571.

${ }^{3}$ Sri Wahyuni Tanshzil, The Model of Character Education Development in the Islamic Boarding School Environment in Building the Independence and Discipline of Santri (A study of the development of Citizenship Education), Jurnal Penelitian Pendidikan Universitas Pendidikan Indonesia, Vol. 12 No. 2, Oktober 2012
} 
conducive classroom climate. In implementing these nine policies, the support of all school members, including principals, teachers, parents, school committees, employees, and students is needed. Also, careful planning is needed to compile school programs. In its implementation, it also needs strong consistency from all school members, especially in terms of program implementation and enforcement of school rules and class rules. ${ }^{4}$

Asroruddin, M. (2020). The Role of Pesantrens in Developing the Discipline Character of Santri (Case Study at the Nurul Haramain NW Putra Narmada Pesantren), the results of the research show that: (1) The role of the NW Putra Narmada Nurul Haramain Pesantren in developing the disciplinary character of the santri is carried out through increasing motivation, education, and training, leadership, enforcement of rules and application of reward and punishment. (2) Obstacles faced in implementing character education in Pesantrens include: students are often tired and in participating in activities so that not a few students have received the punishment, and the character and habits of students who have just entered their initial semester at the Pesantren are still difficult to overcome. , this is due to their inability to adapt to the environment. ${ }^{5}$

Podungge (2020) in his research The Application of Discipline and Its Impact on SelfDevelopment at the Hubulo Pesantren found that the discipline of students at the Hubulo Pesantren was well organized, but in its implementation, it had problems if there was no moral support from every element related to the discipline itself, either students who are endeavored to be disciplined from the start of entry until they finish their education at the pesantren. The driving force for discipline, in this case, the board of the Hubulo Pesantren and ustad-ustazah at the Hubulo Pesantren as well as the parents of the santri who are willing to accept the discipline of the pesantren itself. Forms of self-development for students in extracurricular activities carried out are scouting, recitation, hadrah, basketball, soccer, takraw, volleyball, badminton, table tennis, and pencak silat. The activities that have not been implemented are dance, agriculture, animal husbandry, carpentry, sewing, culinary, printing, and screen printing. The application of discipline has a positive impact, namely, when students can obey the rules well so that they can manage their time and balance their obligations at school and participate in selected extracurricular activities, there is a significant change when students before entering and have undergone the educational process at the Hubulo Pesantren. The application of discipline has a negative impact when students are not ready for mandatory activities in dormitories, schools, and mosques. Santri tends to be lazy and frustrated when time is short and they cannot develop their potential and cannot participate in the activities they have chosen. This is evident in every competition that is followed, often failing to make achievements. ${ }^{6}$

Some of the research results above illustrate how disciplinary character education is applied in various pesantren. The character of this discipline has a positive impact on the personality development of the students. These studies have not yet touched on how students implement the character of discipline not only because of the Covid-19 reason, but it is done solely as a religious order that all Muslims must carry out. This is where this research differs from previous

\footnotetext{
${ }^{4}$ Wuri Wuryandani, Bunyamin Maftuh, Sapriya, dan Dasim Budimansyah, Discipline Character Education in Elementary Schools, Cakrawala Pendidikan, Juni 2014, Th. XXXIII, No. 2, h.286-295.

${ }^{5}$ Asroruddin, M. (2020). The Role of Islamic Boarding Schools in Developing the Discipline Character of Santri (Case Study at the Putra Narmada Nurul Haramain Islamic Boarding School). Jurnal Al-Amin: Kajian Pendidikan Dan Sosial Kemasyarakatan, 5(1), 51-75. Retrieved from http://ejournal.kopertais4.or.id/sasambo/index.php/alamin/article/view/3879.

${ }^{6}$ Mariaty Podungge, Application of Discipline and Its Impact on Self-Development in Pesantren Hubulo, Jurnal EVALUASI, 4 (1), Maret 2020, ISSN 2580-3387 ISSN 2615-2886 (online) Homepage:http://ejournal.staima-alhikam.ac.id/index.php/evaluasi DOI: http://doi.org/10.32478/evaluasi.v4i1.358
} 
studies.

\section{Research Methodology}

This research is field research. The field study was carried out by selecting the Pesantren An-Nisiniyyah Wal Muzainiyyah having its address at Jl. Marsekal Surya Dharma RT 001/07 Gg. Yayasan Pasar Sore Kel. Selapajang Jaya Kec. Neglasari Tangerang City. This pesantren was chosen because no other researcher had conducted research on how the implementation of disciplined character was carried out in the Covid-19 pandemic in this pesantren, with the field research method, researchers went directly to digging data in the field by engaging observations, interviews and conducting descriptions in the field to learn problems in Pondok pesantren about changes in values or views, behavior and ongoing processes and the effects of a phenomenon (Robert Bogdan \& Stevan J Taylor, 1975: 33). ${ }^{7}$

Interviews with caregivers, pesantren administrators, santri, and community leaders, as well as other parties related to the pesantren are intended to hear information from them about facts, events they have experienced and know. (L. Adam, 1952: 5) ${ }^{8}$. In interpreting this research, researchers conducted a literature study by examining various literature, documents, and other works related to this research problem. To further improve the results, during the research and writing, the author used the existing social research methodology. (Atho Mudzar, 1998: 7) .

This research is qualitative-phenomenological. Qualitative research is interested in giving meaning and looking for the essence that it gets itself from religious teaching in Pesantrens and its implementation in the field. Researchers understand the process of developing Pesantren AnNisiniyyah students who face the challenges of modernity. In a phenomenological view, research means understanding events about people in certain situations. (Lexy Moleong, 1995: $23)^{10}$. With the characteristics of this study, the broad direction of the research is to bring together or dialogue between the disciplinary system applied in the pesantren and the influence on the formation of the personality of the students. The data collected includes primary data and secondary data. Primary data was collected through a survey by interviewing several selected respondents, namely the caregivers of Pesantrens, religious teachers, and students who were in Pesantren An-Nisiniyyah. Meanwhile, secondary data collection was carried out on the surrounding population, community leaders, and the head of the local RT.

\section{Result and Discussion}

Pesantren An-Nisiniyyah Wal Muzainiyyah is located at Jl. Marsekal Surya Dharma RT 001/07 Gg. Yayasan Pasar Sore Kel. Selapajang Jaya Kec. Neglasari Tangerang City. This pesantren got No. Establishment of the Foundation: AHU-8116.AH.01.04. The year 2012 with the Date of Establishment of the Foundation: 17 Dec 2012, and received No. Ratification of PN LN: AHU-8116.AH.01.04.Tahun 2012 with No. BN Decree: AHU-8116.AH.01.04. The year

\footnotetext{
${ }^{7}$ Bogdan, Robert \& Stevan J Taylor.1975. Introduction to Qualitative Methods Research, A Phenomenological Approach to Sosial Sciences. New York: John Willey \& Son.

${ }^{8}$ Adam, L. 1952. Methods and Forms of Investigation and Recording of Native Costumary Law in The Netherlands East Indies before the War .Oxford: Oxford University Press

${ }^{9}$ Mudzar, Atho. 1998. Islamic Studies Approach. Yogyakarta: Pustaka Pelajar.

${ }^{10}$ Moleong, Lexy. 1995. Qualitative Research Methodology. Bandung: Rosdakarya
} 


\section{Dated SK BN: 2012-12-17.}

This pesantren was founded by Ust. H. Efendi Nisin ${ }^{11}$ for his concern with the condition of the people of Selapajang at that time, where many people's habits contradicted Islamic teachings such as gambling, drunkenness, and pork fighting. H. Effendi Nisin himself bought land which was a pig pen and places used as gambling places by some members of the community and later built it into a boarding school.

Pesantren An-Nisiniyyah Wal-Muzainiyyah is an orphanage foundation ${ }^{12}$ that was originally established to oversee Koran teaching and learning activities for children around the Foundation, but in subsequent developments at the request of the community, it has increased its role in the form of an orphanage. Apart from these educational activities, pesantren also often conduct skills training for both adolescents and parents. Likewise with youth from youth organizations and mosque youth. Pesantren have also been involved in cooperation with various parties several times to hold religious, social, economic, and cultural activities.

To optimize the role of pesantren in improving the quality of life of the community in various aspects of life, the pesantren strives for economic activities that can increase the income of farmers/breeders. The economic activity referred to is sheep and cattle farming. This activity is a very strategic program for pesantren to increase community income because it is supported by a large area of land for the provision of animal feed and the utilization of livestock and agricultural waste. The land potential to be developed by Pesantren An-Nisiniyah is self-owned land which has a very strategic condition, both geographically and economically, and is supported by the availability of experienced personnel in farming.

\subsection{Vision and mission}

Vision:

a. Forming an Islamic generation capable of implementing the five basic visions of the pesantren, namely: knowledge, charity, preaching, patience, and tawakal.

b. To produce an Islamic generation that is capable of being the successor of the struggles and ideals of the kiai and ulama 'ala thoriqoh ahlussunnah waljama'ah.

Missions:

a. Prepare students who have deep religious scientific abilities and can develop them

b. Preparing students as nationwide cadres who are tough, have faith and devotion to Allah SWT, have a noble character, are skilled, and do good deeds

c. Prepare students who appreciate the values of religious knowledge and humanity

\subsection{Program of Pesantren An-Nisiniyyah Wal Muzainiyyah}

\subsubsection{Orphan Development Program}

This program is a program of building morals, faith, and life skills for orphans who are unable and living (accommodated) through various activities both in Islam, arts, and useful skills training in preparing for their lives in the future. This activity consists of:

1. Islamic Mentoring

\footnotetext{
${ }^{11}$ Ust $\mathrm{H}$. Efendi Nisin is widely active in the community and religious mass organizations, he is one of the FPI mass organizations and his last position as General Treasurer of FPI Banten Province.

${ }^{12} \mathrm{https}: / /$ nisinniyyah.wordpress.com/author/nisinniyyah/. Now in this pesantren, formal educational institutions such as SMP and SMK have developed, where some of the students live in this pesantren.
} 
2. Prayers are obliged to pray in the congregation, to pray Tahajud regularly.

3. Tahfidzul Qur'an, Teaching Arabic and English.

4. Islamic Cultural Arts Training (Nasyid, Hadhrah, Marawis)

5. Sending students to attend computer training.

6. Providing donations on every Islamic holiday for the children who are accommodated.

7. Funding teachers at the Orphaned Pesantren - Piatu An-Nisiniyyah Wal - Muzainiyyah

8. Hold activities every major Islamic day

9. Developing Talents and Potential of Foster Children (Orphans and Fuqoro)

10. Creating Foster Children (Orphans and Fuqoro) who have noble and Islamic character

11. In the month of Ramadan, give clothes, pants, and shoes.

12. Holding regular recitation of book studies every day (ba'da maghrib and dawn)

\subsubsection{Education Fees Program}

The Education Fee Program is a program of providing education fees for all orphans who cannot afford and live to attend school from elementary, junior high, senior high school and some even have continued their studies. This Education Fee covers all school needs for students which include: School supplies (uniforms, shoes, textbooks/packages, stationery, bags, etc.). The Tuition Fee Program also includes the entire cost of education such as construction fees, tuition fees, semester examinations, final examinations, study tours, transportation fees, etc., which are used as funding for the Foundation considering the condition of students who are very poor and do not have parents.

\subsubsection{Bina Prestasi Orphans}

The Bina Prestasi Yatim Program is a coaching and training program for all orphaned santri who live in order to improve their school performance both academically and nonacademically in the form of computer training.

\subsubsection{Long Term Program}

It has become a strong and sincere commitment for all administrators to continue to improve the quality of institutional management and guidance for all orphaned santri that economic limitations and financial capabilities do not necessarily mean a loss of opportunities and opportunities for this young generation to become the best and excel in their lives. Therefore, in the future, Pesantren An-Nissiniyyah Wa Al-Muzainiyyah, Insyaa Alloh, will carry out the following programs and activities:

1. Expanding the Institution Location Area

2. Build learning spaces and skills practice.

3. Organizing courses - skills courses (computers, sewing, and electronics).

4. Organizing the Equalization / Pursuing Package Education Program

5. Development of Agribusiness Entrepreneurship

\subsection{Pesantren The Safest Place; No Covid-19 and New Normal}

It is common knowledge that the world is currently being hit by the Covid Pandemic 19 . Even the case of Indonesia every day continues to experience significant increases. This has an impact on all sectors of life, and one of them is education. Schools, madrasas, pesantren, and other educational institutions that usually carry out educational activities normally, are now faced with a very difficult situation, namely carrying out the learning process abnormally. Most 
of them do distance learning or Home Study (BDR). Most boarding schools, including Pesantrens, have sent their students home because they are worried about the spread of Covid19.

But it is different from Pesantren An-Nisiniyyah Wal-Muzainiyyah. During the Covid 19 era, Pesantren An-Nisiniyyah Wal-Muzainiyyah did not send its students home like other Pesantrens. The pesantren is very confident, bringing Pesantren An-Nisiniyyah WalMuzainiyyah very safe from various diseases including Covid-19. Learning activities are running normally as usual. Santri, ustad, and education personnel were not sent home, let alone on holidays. When carrying out learning activities, students, clerics, and education personnel are not required to follow strict health protocols as recommended by the government, including wearing masks, washing hands, and keeping a distance. Santri and all members of the pesantren are not required to do this, because the leadership of the pesantren is sure that the Pesantren AnNisiniyyah Wal-Muzainiyyah is very safe from the things that have been worried about. Pesantrens are considered sterile from various epidemics, especially female students, and their ustads are already accustomed to wearing the veil.

According to the leadership of Pesantren An-Nisiniyyah Wal-Muzainiyyah, Ust. H. Efendi Nisin, personally he believes that Covid-19 does not exist, he does not believe in Covid-19. Covid is a human creation. Everyone that Covid says is not Covid. According to him, Covid-19, which has been reported so far, is not a dangerous virus but an ordinary bacteria that can be cured with village medicine. These bacteria can be lost by drinking bodrex, paracetamol, and areca nuts, both young and old. He has proven this to people who are suspected of having Covid19 , by being given these drugs it turns out to be able to recover quickly.

The virus that is considered Covid 19 according to H. effendi Nisin is no more dangerous than dengue fever. So far, people have been afraid of Covid-19 reports. According to him, Covid -19 is a business tool for certain parties. Many patients were treated and said to have been exposed to Covid-19, even though they were not actually Covid-which in H. Nisin's terms, these people were Covided. The Covid-19 issue is a political matter, everything has been designed and regulated massively by business people from Indonesia and also international businessmen.

Although Pesantren An-Nisiniyyah Wal-Muzainiyyah does not internally follow the health protocols required by the government, such as wearing masks, maintaining distance, providing a place to wash hands, washing hands with soap, but institutionally the pesantren respects government policies. This was proven when students, religious teachers, or administrators left the pesantren - for a purpose, for example, they were obliged to follow government regulations, namely carrying out health protocols such as wearing masks, washing hands, maintaining distance, and so on. As citizens, pesantren residents must obey the rules.

Even when the government is now declaring New-Normal, or New Habit Adaptation (AKB), according to Pesantren An-Nisiniyyah Wal-Muzainiyyah in this pesantren there is no term New-Normal, because the pesantren from the beginning did not believe in the existence of Covid-19, so the pesantren from Initially, he had carried out various pesantren activities normally not affected by the conditions of the Covid-19 Pandemic that hit Indonesia and the world today. Persantren understands the term New Normal with the term pesantren itself, which is to maximize one's own approach to Allah (taqarraub ilallah). Muslims must return to the right path by increasing their faith so that they are kept away from various disease outbreaks. If all this time the worship has not been maximal, then in the future it can be further improved. So to prevent the santri from being contaminated by various reports from outside, the pesantren applies strict permits for the students to leave the pesantren, let alone go home.

The data above shows that the leadership of Pesantren An-Nisiniyyah Wal-Muzainiyyah believes that there is a conspiracy in Covid-19. The Covid-19 conspiracy theory always starts 
and ends with parties who benefit from the outbreak. ${ }^{13}$ It's just that, it is very difficult if you don't want to say impossible, to estimate the benefits that will be obtained from a pandemic that creates global uncertainty. Countries lose their income. The government is in danger of being overthrown. Businesses collapsed and demanded stimulus from the state in order to survive.

On the other hand, the policy of Pesantren An-Nisiniyyah Wal-Muzainiyyah, which does not send students home and continues to learn, as usual, is very appropriate to do in the pesantren environment because the pesantren does have a characteristic lockdown from the outside environment. That is, if the rules (health protocols and can be adapted to the pesantren environment) above are enforced in a disciplined and correct manner, especially regarding the traffic of people in and out of the pesantren, by limiting (if possible, temporarily prohibiting) meetings with guests and visiting parents. students, the pesantren environment is the safest place from the spread of Covid-19.

On the other hand, if the pesantren is still half-heartedly implementing its rules by still allowing guests and guardians of the santri to visit, then the pesantren will be the same as other places and could be even riskier. This is what is now happening, where the pesantren sometimes still receives guests from outside even though they are in a place specially prepared for this. The Covid-19 case must be a moment to strengthen tarbiyyah ${ }^{14}$ or education for all Muslims, especially Muslims, to always strengthen discipline in various matters, including a clean lifestyle to avoid various outbreaks.

\subsection{Discipline Character Education; Pesantren Strategies in Facing Covid-19}

Character education is the process of giving, planting, and character-building by teachers for students. Character education is the main foundation in building national character. ${ }^{15}$ In education, the discipline has an important function to be instilled in students, so that the development of social attitudes and student learning outcomes will be achieved. The character of discipline in students will be seen through the actions and actions that are carried out in their daily routines at school. The functions of discipline are: a) managing life together; b) build personality; c) train a good personality; d) coercion; e) create a conducive environment. If these five functions can be implemented and coupled with good support, they will achieve the expected results.

The application of disciplinary character values can be carried out in various routines in the environment of students. One of them is in the pesantren environment, where most of the time spent by students is in the pesantren environment. The pesantren environment greatly influences the character formation of students, both activities related to learning and activities outside of class hours. In the learning process of the Pesantren An-Nisiniyyah Wal-Muzainiyyah emphasized the discipline of students in learning Tahfid Al-Quran and the yellow book such as Nahwu, Sharaf, and Fiqih. In addition, students are also required to congregate every five prayers.

In the face of the Covid-19 outbreak that is currently hitting Indonesia and the world, Pesantren An-Nisiniyyah Wal-Muzainiyyah emphasizes disciplinary character education for all

\footnotetext{
${ }^{13}$ https://www.tempo.co/dw/2739/korban-teori-konspirasi-covid-19-bukan-hanya-kecerdasanpenganutnya (Akses, 30 Juni 2020).

${ }^{14}$ Tumpal Daniel S, Strengthening Tarbiyah Umat and Contribution of Islam to Overcome Covid 19, Alasma Jurnal Media Informasi dan Komunikasi Ilmiah, Volume 2 (1), 2020, h. 19. https://jurnalstitmaa.org/alasma/issue/view/3

${ }^{15}$ Faizal Chan, Agung Rimba Kurniawan, Lia Gusti Melinda, Rattu Priantini, Zubaedah, Siti Reni Suharti, dan Siti Khodijah, Implementation of Discipline Character Education in Students at SD Negeri 187 Teratai, Jurnal Pendas Mahakam. Vol 4 (2). 137-145. Desember 2019.
} 
pesantren residents by emphasizing discipline in several things, namely discipline in maintaining ablution, discipline in maintaining cleanliness, discipline in wearing the veil. for women and discipline in hygiene, especially washing hands with soap or using a hand sanitizer.

Discipline in maintaining ablution is applied because ablution is not just a legal requirement to perform prayer. Ablution is also part of faith. In addition, ablution has an important virtue for daily life, namely maintaining cleanliness and health. In connection with the outbreak of Covid-19 which has infected humans, Pesantrens are of the opinion that with ablution the corona virus can stay away and disappear. Wudu is one of the steps to avoid being attacked by the corona virus. The corona virus will go away on its own with water and maintain cleanliness. Wudu is a way to avoid the corona virus. These viruses will quickly be destroyed with water, especially Muslims do ablution 5 times a day and clean their mouths, noses, and other body parts, and that is a separate grace apart from the values of worship that exist in Islam. The viruses will die when a person performs ablution. So the students at the Pesantren AnNisiniyyah Wal-Muzainiyyah are taught to be disciplined in maintaining ablution under any conditions.

True Muslims cannot be separated from maintaining cleanliness. Clean is faith. Maintain personal hygiene, environmental cleanliness, and mental hygiene. Adopting a clean lifestyle starting from yourself, the environment, and society. The cleaner is free of dirt. Not stained. Clean is a way of life. A clean and holy life will make humans physically and mentally healthy. Islam loves cleanliness and purity. Not only physical but also mental. That is why clean life is a very important initial capital for every human being to face life positively. Humans need to maintain personal hygiene so that they are healthy, not smelly, not dirty, not spreading dirt, or transmitting germs to themselves or others. Body hygiene includes oneself such as bathing, brushing teeth, washing hands, and wearing clean clothes. Washing can also be categorized as a way to maintain cleanliness. Islam does not teach dirty things, because being dirty creates bad effects. By always maintaining a clean and healthy lifestyle, we will avoid various diseases so that we will become healthy and strong people, and give birth to a generation that is healthy and strong as well.

One of the clean and healthy living habits (PHBS) taught by Pesantren An-Nisiniyyah Wal -Muzainiyah to maintain health and personal hygiene is washing hands. Hands are a very powerful medium for transferring disease because they are used to hold objects that we often do not know for sure, their cleanliness. Washing your hands is highly preferred at important times, including before eating, after defecating, before touching food, and after activities. In doing this handwashing, students are encouraged to use soap or use a Hand Sanitizer that has been distributed to each student.

In the midst of the rapidly growing corona outbreak, one of the recommended habits is wearing a mask. However, Pesantren An-Nisiniyyah Wal Muzainiyyah responded to this by requiring female students to wear a veil. And as we know, face masks are one of the ways used to avoid transmission of the Corona virus. Likewise, with the use of the veil for women, pesantren believes that this can protect women from various impurities and diseases.

\subsection{Implications of Discipline Character on Santri Personality}

The disciplinary character education developed by Pesantren An-Nisiniyyah WalMuzainiyyah is believed to have an impact on several things for students, namely increasing faith, increasing body immunity, being strong and healthy, and most importantly being successful in studying. In the case of the corona virus, every believer is obliged to believe that this invisible micron creature is also His creation. And that Allah created everything according 
to his qodar. Allah has created fire to have qodar (khosiyat) burn. Allah has created a virus with qodar that can infect the host and cause illness. Allah has also created humans with qodar to have the mind to think about the signs of Allah's power. So this can become a medium for students to further increase their faith in Allah SWT. For a santri as a Muslim who believes in Allah, of course, he must always remember Allah. Strengthen the belief that Allah is the Creator and Most Regulatory. Everything that He creates must comply with His rules.

The disciplinary character developed by Pesantren An-Nisiniyah Wal-Muzainiyah can increase the body's immunity for students, this is because the pesantren adopts the three methods taught by the Prophet, namely Qiyamul Lail, recitation of the Quran, and Fajr prayer. Qiyamul Lail is performed by the students at least 2 cycles or at least 10 minutes before dawn. Reading the holy book Al-Qur'an while doing Qiyamul Lail is believed to also increase body immunity. Meanwhile, another way to increase immunity at the beginning of another morning is by performing the Fajr prayer. Fajr prayer will make us guaranteed by Allah. Guaranteed sustenance, guaranteed safety. Also, God willing, his safety is guaranteed from the Corona virus outbreak. Those are the three ways that the students do to make their immunity or immune system increase. With this Islamic-style protocol, the students are expected to be healthier and stronger in carrying out their knowledge-seeking activities at the pesantren. The character of discipline developed by this pesantren is expected to be able to encourage a santri to be successful and successful in achieving the curriculum targets required by the pesantren.

The discipline of the santri at the An-Nisiniyah Wal-Muzainiyah pesantren is quite good because the students can still be given guidance regarding discipline through the rules of the pesantren that apply. The disciplinary problem that exists in the pesantren is the delay in arriving on time for the recitation. The delay occurs due to several factors, such as students who are late to wake up, so they are late entering class. When there are students who violate the rules, the pesantren caregivers will give sanctions in the form of reading the Al-Qur'an $3 \mathrm{Juz}$, then the sanctions are not physically oriented or violent. The factors that influence the discipline of students at Pesantren An-Nisiniyah Wal-Muzainiyah are internal factors that come from the students themselves, in addition to external factors in the form of encouragement from parents greatly influencing student discipline in schools.

The efforts made by the pesantren to improve the discipline of students in the form of reinforcing the disciplinary values that students must have, such as arriving on time, and dressing politely and neatly. Santri are not allowed to leave the dormitory, including to buy daily necessities from a place that has been determined by the pesantren, namely the cooperative that has been provided. Communication between parents and the pesantren in student discipline runs well, teachers and parents work together in shaping student discipline.

\section{Conclusion}

During the Covid-19 era, Pesantren An-Nisiniyyah Wal-Muzainiyyah did not send its students home like other Pesantrens, because the pesantren was very sure that Covid-19 did not exist, the pesantren leadership did not believe in the existence of Covid-19. Covid is a human creation. Covid-19, which has been reported so far, is not a dangerous virus, but ordinary bacteria that can be cured with village medicine. These bacteria can be lost by drinking bodrex, paracetamol, and areca nuts, both young and old. The virus that is considered Covid 19 is no more dangerous than DBD.

Pesantren An-Nisiniyyah Wal-Muzainiyyah is very safe from various diseases including Covid-19. Learning activities are running normally as usual. When carrying out learning 
activities, students, clerics, and education personnel are not required to follow strict health protocols as recommended by the government, including wearing masks, washing hands, and keeping a distance. Santri and all members of the pesantren are not obliged to do this, because the leadership of the pesantren is sure that Pesantren An-Nisiniyyah Wal-Muzainiyyah is very safe from the things that have been of concern. Pesantrens are considered sterile from various epidemics, especially female students, and their ustazahs are already accustomed to wearing the veil. Although Pesantren An-Nisiniyyah Wal-Muzainiyyah is internally unsure and believes in Covid-19, institutionally as a good citizen, the pesantren respects what is the government's policy. This was proven when students, clerics, or administrators left the pesantren - for some purpose, for example - then, the person concerned was obliged to follow government regulations, namely carrying out health protocols such as wearing masks, washing hands, maintaining distance, and so on.

In the face of the Covid-19 outbreak - even though Pesantrens are unsure and confident that is currently hitting Indonesia and the world, Pesantren An-Nisiniyyah Wal-Muzainiyyah emphasizes disciplinary character education for all pesantren residents by emphasizing discipline in several matters, namely discipline in maintaining ablution, discipline in maintaining cleanliness, discipline in wearing the veil for women and discipline in hygiene, especially washing hands with soap or using hand sanitizers.

The disciplinary character education developed by Pesantren An-Nisiniyyah MalMuzainiyyah is believed to have an impact on several things for students, namely increasing faith, increasing body immunity, being strong and healthy, and most importantly being successful in studying. The efforts made by the pesantren to improve the discipline of students in the form of reinforcing the disciplinary values that students must have, such as arriving on time, and dressing politely and neatly. Santri are not allowed to leave the dormitory, including to buy daily necessities from a place that has been determined by the pesantren, namely the cooperative that has been provided. Communication between parents and the pesantren in student discipline runs well, teachers and parents work together in shaping student discipline.

From the results of the research presented above, the researchers recommend the following: (1) The government through the Covid-19 Spread Prevention Task Force, should socialize about the dangers of the Corona Virus by coming directly to the An-Nisiniyyah Mal-Muzainiyyah Pesantren, (2) the Government through the Ministry Religion, the Ministry of Health and the Regional Government should communicate well with the An-Nisiniyyah Mal-Muzainiyyah Pesantren about the dangers of the Corona Virus, and make every effort to ensure that the Corona virus is true, and is a very dangerous virus in the world, (3) Pesantren An-Nisiniyyah Mal-Muzainiyyah should see the true fact that Covid 19 not only exists and threatens the Indonesian people but also the world.

Acknowledgments. The author would like to thank all those who contributed to this research. First, to the Head of Center for Religious and Religious Education Religious Research, Development and Training Agency, Ministry of Religious Affairs. Second, to Ust. Effendi Nisin who has permitted for the author to research on this Pesantren, all the Ustads and santri at the Pesantren An-Nisiniyah Wal-Muzainiyah, who have provided data and information to the author. Hopefully, this research will be useful for the development of pesantren in Indonesia. 


\section{References}

[1] Adam, L. Methods and Forms of Investigation and Recording of Native Costumary Law in The Netherlands East Indies Before The War .Oxford: Oxford University Press. 1952.

[2] Asroruddin, M.. Peran Pondok Pesantren dalam Mengembangkan Karakter Disiplin Santri (Studi Kasus di Pondok Pesantren Nurul Haramain NW Putra Narmada). Jurnal Al-Amin: Kajian Pendidikan Dan Sosial Kemasyarakatan. 2020; vol. 5(1), 51-75.Retrieved from http://ejournal.kopertais4.or.id/sasambo/index.php/alamin/article/view/3879.

[3] Bogdan, Robert \& Stevan J Taylor. Introduction to Qualitative Methods Research, A Phenomenological Approach to Sosial Sciences. New York: John Willey \& Son. 1975.

[4] Faizal Chan, Agung Rimba Kurniawan, Lia Gusti Melinda, Rattu Priantini, Zubaedah, Siti Reni Suharti, dan Siti Khodijah , Implementasi Pendidikan Karakter Disiplin Pada Peserta Didik Di Sd Negeri 187/1 Teratai, Jurnal Pendas Mahakam. Vol 4 (2). 137-145. Desember 2019

[5] https://nisinniyyah.wordpress.com/author/nisinniyyah/.

[6] https://www.tempo.co/dw/2739/korban-teori-konspirasi-covid-19-bukan-hanya-kecerdasanpenganutnya (Akses, 30 Juni 2020).

[7] I Putu Yoga Purandina dan I Made Astra Winaya, Pendidikan Karakter di Lingkungan Keluarga Selama Pembelajaran Jarak Jauh pada Masa Pandemi COVID-19, Cetta: Jurnal Ilmu Pendidikan, Jayapangus Press ISSN 2615-0913 (E) Vol. 3 No. 2 (2020). https://doi.org/10.37329/cetta.v3i2.454.

[8] Imam Prawoto, Siti Ngainnur Rohmah, Fitri Rachmiati Sunarya, Peran Preventif Pemimpin Dalam Pencegahan Penyebaran COVID-19; Strategi Syaykh Al-Zaytun di Ma'had Al-Zaytun dan Kontribusinya Terhadap Masyarakat Sekitar, SALAM; Jurnal Sosial \& Budaya Syar'i FSH UIN Syarif Hidayatullah Jakarta Vol. 7 No. 5 (2020), pp. 403-422, DOI: 10.15408/sjsbs.v7i5.15571

[9] Mudzar, Atho. Pendekatan Studi Islam. Yogyakarta: Pustaka Pelajar. 1998.

[10] Moleong, Lexy. Metodologi Penelitian Kualitatif. Bandung: Rosdakarya. 1995.

[11] Mariaty Podungge, Penerapan Disiplin Dan Dampaknya Terhadap Pengembangan Diri Di Pesantren Hubulo, Jurnal EVALUASI, 4 (1), Maret 2020, ISSN 2580-3387 ISSN 2615-2886 (online) Homepage : $\quad$ http://e-journal.staima-alhikam.ac.id/index.php/evaluasi $\quad$ DOI :http://doi.org/10.32478/evaluasi.v4i1.358

[12] Sri Wahyuni Tanshzil, Model Pembinaan Pendidikan Karakter Pada Lingkungan Pondok Pesantren Dalam Membangun Kemandirian Dan Disiplin Santri (Sebuah kajian pengembangan Pendidikan Kewarganegaraan), Jurnal Penelitian Pendidikan Universitas Pendidikan Indonesia,Vol. 12 No. 2, Oktober 2012.

[13] Tumpal Daniel S, Penguatan Tarbiyah Umat Dan Kontribusi Islam Atasi Covid 19, Alasma Jurnal Media Informasi dan Komunikasi Ilmiah, Volume 2 (1), 2020, h. 14. https://jurnalstitmaa.org/alasma/issue/view/3.

[14] Wuri Wuryandani, Bunyamin Maftuh, Sapriya, dan Dasim Budimansyah, Pendidikan Karakter Disiplin Di Sekolah Dasar, Cakrawala Pendidikan, Juni 2014, Th. XXXIII, No. 2, p.286-295. 